\title{
Application of Polymer as Chemical Enhanced Oil Recovery for Increasing Quantity of Crude Oil Resorcer
}

\author{
Oksil Venriza $^{1, *}$ Puspa Ratu ${ }^{2}$ Andian Ari Instiningrum ${ }^{1}$ \\ ${ }^{1}$ Logistic Oil and Gas of Department, Polytechnic Energy and Mineral Akamigas, 58315, Cepu, Indonesia \\ ${ }^{2}$ Refranery of Department, Polytecnic Energy and Mineral Akamigas, 58315, Cepu, Indonesia \\ *Corresponding author. Email: drphiloksil10@gmail.com
}

\begin{abstract}
Chemical injection using Polymer is expected to increase the pressing efficiency and sweeping efficiency so that the oil recovery can increase after the flood of water from the initial oil reserve (OOIP) in the reservoir. This research will carry out the stages of making polymers that are hygroscopic against EOR conditions. This time the polymer is made using Glycidyl Methacrylate (GMA) as a monomer, Ethylene Dimehacrylate (EDMA) as Croslinker and alcohol group solvent as a porogen and trimethylamine as active group formers. These polymers are expected to be polymers that have amine and hydroxyl functionalities and are synthetic organic polymers. Provision of variations in polymer concentrations of $10 \mathrm{ppm}, 20 \mathrm{ppm}$, and $50 \mathrm{ppm}$, as well as for variations in salinity of 1000 and 10,000 ppm. Meanwhile, the Trimetylamine concentration was $0.5 \%$ and $1 \%$. In this situation, optimal conditions are obtained at a polymer concentration of $50 \mathrm{ppm}$ with Trimeylamine $1 \%$ at a salinity of $10,000 \mathrm{ppm}$, meaning that there is a linearity relationship between the increase in concentration and the resulting interface stress. This condition needs to be developed again to obtain stabilization and suitability for the repetition process to increase the production of old wells. The test will be carried out at a temperature of $85^{\circ} \mathrm{C}$ and an observation of the physical properties of the fluid between viscosity and interface tension (Inter Facial Tension) will be carried out. To see a comparison of the physical properties of the fluid between the polymer and production water.
\end{abstract}

Keywords: GMA, EDMA, Polymer, Interface Interaction, Salinity.

\section{INTRODUCTION}

Crude oil (crude oil) is a thick black liquid and smells unpleasant. Crude oil cannot be used as fuel or for other purposes, but it must be processed first. Crude oil contains about 500 types of hydrocarbons with the number of $\mathrm{C}-1$ to 50 atoms. The boiling point of hydrocarbons increases as the number of $\mathrm{C}$ atoms in the molecule increases. Therefore, petroleum processing is carried out through multilevel distillation, where crude oil is separated into groups (fractions) with nearly the same boiling point. The refining process is first of all converting the oil component into salable fractions in the form of several types of distillation. Several chemical treatments and heating were carried out to improve the quality of the crude oil product obtained. For example, in 1912 demand for Gasoline exceeded supply and to meet this demand high "heating" and "pressure" processes were used to change the fraction that was not expected.
Large molecules become smaller in the boiling point range of gasoline, this process is called cracking.

Gasoline is one of the most widely used fuel products from petroleum processing. Meanwhile, the fraction of Gasoline in petroleum is very small. Therefore, to increase the number of Gasoline fractions it is necessary to carry out a cracking process for long chain hydrocarbons. Gasoline is a mixture of heptane $\left(\mathrm{C}_{7} \mathrm{H}_{16}\right)$ and octane $\left(\mathrm{C}_{8} \mathrm{H}_{18}\right)$ isomers. The octane number is a number that states the quality of gasoline, where the greater the octane number of gasoline, the better the quality, which means that the combustion in the engine can take place perfectly. Gasoline, which is composed of straight-chain hydrocarbons, turns out to be of poor quality and there are several disturbing compounds which are commonly called impurity compounds. This is because the gasoline can cause uncontrolled ignition (knocking or knocking) of the engine so that the engine 
vibrates very violently and causes too high heat. If this happens, the machine will break down quickly.

In gasoline also has an indispensable TEL in gasoline because it can reduce the vibration in the engine so that it will add to the security of the wearer. But in addition to this convenience, it turns out TEL in gasoline can cause very serious problems for the welfare of mankind. This is because the fuel combustion process, the particles of lead (from TEL) were released and exhaled into the air so that the air polluted by particles of lead. Lead particles that are inhaled by us while breathing can cause serious problems such as damage to the spinal cord (blocking the formation of hemoglobin), causing enzyme problems, and irritation of the respiratory tract. Nowadays TEL has begun to be reduced even in countries forward is deprecated. As a substitute for TEL to increase the octane rating used dibrom ethane $\left(\mathrm{C}_{2} \mathrm{H}_{4} \mathrm{Br}_{2}\right)$, methyl tertiary butyl ether (MTBE).

According to the Downstream Oil and Gas Regulatory Agency (BPH Migas), the average Indonesian fuel consumption per year is 50 million kilom liters, both subsidized and non-subsidized, of course this is an enormous amount and requires availability of adequate supply and stock. To meet this consumption, domestic refineries must be optimized as well as being met by importing fuel. However, there are still problems in every petroleum product in Indonesia, for example the fuel produced by RU V Balikpapan processing is still high in chlorine in BBM, causing very high corrosiveness.

In recent years, oil production has decreased, while oil consumption has always increased. One of the causes is the decline in oil production due to the decrease in the amount of discovered oil reserves. To cope with the decline in petroleum production, in the last few years, advanced draining technology (EOR) has been developed in old oil wells which still have a significant amount of oil left in the reservoir. It was recorded that the total old oil wells in Indonesia were 13,824 wells. The locations of these wells are in East Kalimantan with 3,143 units, southern Sumatra 3,623 units, northern Sumatra 2,392 units, Central Java and East Java 2,496 units, central Sumatra 1,633 units, Seram 229 units, Papua 208 units, and South Kalimantan 100 units. There are 3 methods of extraction, namely primary recovery method, secondary recovery method, and tertiary recovery. After a long period of production, the hydrocarbon field will experience a decrease in production, the cause is in the primary recovery (natural flow) stage which cannot flow independently. To increase field drainage, a secondary recovery (water flooding) stage is carried out. When the secondary stage is not optimal yet, a tertiary recovery stage is carried out which is often referred to as the EOR (Enhanced Oil Recovery) method to further optimize field drainage. EOR has 3 kinds of methods, namely thermal, gas miscible, and chemical flooding. The thermal and gas miscible methods can change the characteristics of the fluid, while the chemical flooding method can change the characteristics of the fluid and the rock. One of the chemical flooding methods is polymer injection. Polymer injection can release the oil stuck to the rock.

Polymer technology can be used as a way to reduce disruptive compounds in fuel products in Indonesia. This technology has been used several times with polysaccharide materials [1], where the polymer to be made has good permeability and very high selectivity. Many methods have been used to process fuel into fuel that has good quality, but it involves reagents and techniques that are expensive and long. Therefore, we need a methodology that can provide cheap and efficient fuel processing techniques and produce fuel oil that has characteristics that are in accordance with high quality standards and increases oil production [2]. In addition to polymer, carbon dioxide is also used to increase oil production, but at different oil conditions, the saturation is very high and the permeability is low [3]. Therefore, it is necessary to do with polymer compounds that are more resistant to thermal and have good permeability.

This research is expected to be useful for developing knowledge in the field of chemical drainage of polymer types, the effect of polymer concentration, and its utilization on increasing oil recovery, so that understanding it can recover remaining oil, resulting in lower costs. The main reason for conducting research on the Application of Polymerization Technology to Improve the Quality of Oil and Gas Products where the fuel is the viscosity of old wells is high which results in high cosh, increase the amount of crude oil produced in old wells so that it can be used by the general public and polymer formation process will use monomers, copolymers, cross-linkers and several types of organic solvents that are resistant to hydrocarbon compounds in BBM. The aims and objectives to be achieved in research are obtain acrylatamine based polymer products to remove interfering compounds in the oil, increase the amount of old well oil production and obtaining the characteristic test results of old wells in accordance with good quality standards.

\section{METHOD}

Polymethacrylate based hydrofilik group were prepared by thermal copolymerization of GMA as monomer, EDMA as crosslinker using binary porogenic solvents in. In this work, Trimethylamine was dissolved in organic solvent and was attached on the surface polymer using hydrochloric acid as catalyst. Poly(GMAEDMA) modified with $250 \mathrm{mM}$ trimethylamine was optimised for enhanced oil recovery. The polymers were prepared from polymerization reaction of mixtures, consisting of the monomers GMA, EDMA, the porogens of isopropanol and decanol using $\operatorname{AIBN}(0.3 \%$, w/w, with 
respect to the monomers) as an initiator, $0.5 \mathrm{~mL}$ of this solution and $0.5 \mathrm{~mL}$ of trimetylamine solution were mixed. The polymerization mixtures were sonicated for 5 min to obtain homogeneous solution, and keep at room temperature for $30 \mathrm{~min}$ and allowed to react at $60-100{ }^{\circ} \mathrm{C}$ for 2 hours. Finally, the structure of polymer for EOR has a positive charge of trimethyamine, as shown in Figure 1.
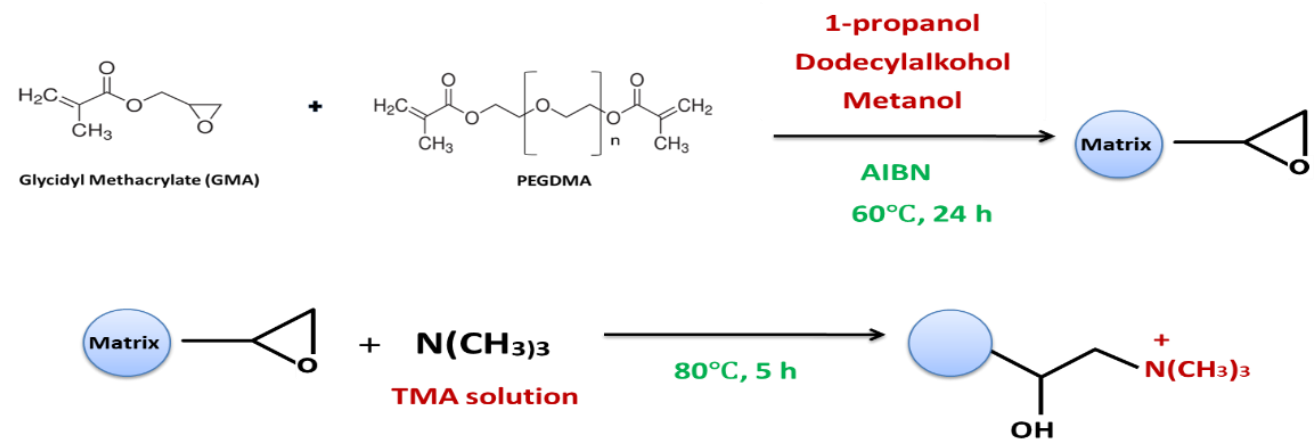

Figure 1 Schematic diagram of the expected reaction for preparation of poly(GMA-EDMA)-trimethylamine

For the characterization of prepared polymer scanning electron microscopy (SEM) technique is used. SEM technique is briefly based on the principle of scanning probe consisting of a focused electron beam emitted from an electron gun, which scans the surface of the specimen.

\section{RESULT AND DISCUSSION}

The objective of this study is to measure the viscosity of polymer solutions with different range of concentration. As a compliment, the interfacial tension of seleced sample will be performed. Based on the background and the problem stated, the scopes of the research are: a. Measure viscosity of synthetic brine $(\mathrm{NaCl})$ at 1,000 ppm and 10,000 ppm concentration as reference b. Measure viscosity of polymer solutions; $1,000 \mathrm{ppm}$ and 10,000 ppm c. Measure interfacial tension of synthetic brine and selected polymer solutions. The performance polymers for water production system was observed with optimum composition solution. And the evaluation result was used SEM for porosity characteristic polymer.

\subsection{Results}

The composition of the monomer and cross linker at a ratio of $20: 80 ; 25: 75 ; 50: 50 ; 75: 25 ; 80: 20$ was observed with temperature variations of $60,70,80$, and $90 \mathrm{oC}$. In this variation the optimum conditions are obtained at a ratio of $80 \%$ monomer and $20 \%$ monomer. After obtaining these variations, variations in the concentration of porogen were also carried out by mixing in 30 minutes. The best of solution polymer was evaluated for interaction performance with synthetic brine solution, as shown in Table 1. Table 2 shows the result of interfacial tension measurement for selceted polymer solutions; Polymer 310,000 ppm $(\mathrm{NaCl} 1,000 \mathrm{ppm})$. The measurement use light oil with $0.831 \mathrm{~g} / \mathrm{cc}$ in density. And Figure 2 shows the porosity of polymer.

Table 1. Viscosity Performace Polymer with water production.

\begin{tabular}{|c|c|c|c|c|c|c|c|c|c|c|c|c|c|}
\hline \multirow[b]{2}{*}{ No } & \multirow{2}{*}{$\begin{array}{l}\mathrm{NaCl} \\
\text { Conc. } \\
\text { (ppm) }\end{array}$} & \multicolumn{2}{|c|}{ Polymer } & \multicolumn{4}{|c|}{ Summary 1} & \multicolumn{4}{|c|}{ Summary 2} & \multirow{2}{*}{$\begin{array}{c}\text { Average } \\
\text { Viscosity } \\
\text { (cR) }\end{array}$} & \multirow[b]{2}{*}{ Remarks } \\
\hline & & Type & $\begin{array}{l}\text { Conc. } \\
\text { (ppm) }\end{array}$ & $\begin{array}{l}\text { Viscosity } \\
\text { (cE) }\end{array}$ & $\mathrm{n}$ & K & $\begin{array}{c}\text { Measure } \\
\text { ment }\end{array}$ & $\begin{array}{c}\text { Viscosity } \\
\text { (ce) }\end{array}$ & $\mathrm{n}$ & $\mathrm{K}$ & $\begin{array}{c}\text { Measure } \\
\text { ment }\end{array}$ & & \\
\hline 1 & 1,000 & & - & 0.68 & 0.855 & 0.017 & 1 & 0.65 & 0.96 & 0.01 & 2 & 0.66 & $\begin{array}{l}\text { Newtonian } \\
\text { Fluid }\end{array}$ \\
\hline 2 & 10,000 & & - & 0.67 & 0.913 & 0.012 & 1 & 0.65 & 0.94 & 0.01 & 2 & 0.66 & $\begin{array}{c}\text { Newtonian } \\
\text { Fluid }\end{array}$ \\
\hline 3 & 1,000 & Polymer 1 & 2,000 & 0.67 & 0.868 & 0.015 & 1 & 0.7 & 0.890 & 0.013 & 2 & 0.67 & $\begin{array}{c}\text { Newtonian } \\
\text { Fluid }\end{array}$ \\
\hline 4 & 1,000 & Polymer 1 & 10,000 & 0.67 & 0.884 & 0.014 & 1 & 0.7 & 0.814 & 0.022 & 2 & 0.67 & $\begin{array}{c}\text { Newtonian } \\
\text { Fluid }\end{array}$ \\
\hline 5 & 10,000 & Polymer 1 & 2,000 & 0.67 & 0.902 & 0.012 & 1 & 0.65 & 0.941 & 0.009 & 2 & 0.66 & $\begin{array}{l}\text { Newtonian } \\
\text { Fluid }\end{array}$ \\
\hline 6 & 10,000 & Polymer 1 & 10,000 & 0.67 & 0.941 & 0.010 & 1 & 0.66 & 0.953 & 0.009 & 2 & 0.66 & $\begin{array}{c}\text { Newtonian } \\
\text { Fluid }\end{array}$ \\
\hline 7 & 1,000 & Polymer 2 & 2,000 & 0.65 & 0.938 & 0.010 & 1 & 0.66 & 0.927 & 0.010 & 2 & 0.65 & $\begin{array}{c}\text { Newtonian } \\
\text { Fluid }\end{array}$ \\
\hline 8 & 1,000 & Polymer 2 & 10,000 & 0.66 & 0.847 & 0.017 & 1 & 0.67 & 0.893 & 0.013 & 2 & 0.66 & $\begin{array}{c}\text { Newtonian } \\
\text { Fluid }\end{array}$ \\
\hline 9 & 10,000 & Polymer 2 & 2,000 & 0.67 & 0.913 & 0.000 & 1 & 0.66 & 0.905 & 0.012 & 2 & 0.66 & $\begin{array}{c}\text { Newtonian } \\
\text { Fluid }\end{array}$ \\
\hline 10 & 10,000 & Polymer 2 & 10,000 & 0.66 & 0.950 & 0.009 & 1 & 0.67 & 0.834 & 0.019 & 2 & 0.66 & $\begin{array}{c}\text { Newtonian } \\
\text { Fluid }\end{array}$ \\
\hline 11 & 1,000 & Polymer 3 & 2,000 & 0.74 & 0.389 & 0.342 & 1 & 0.65 & 0.864 & 0.015 & 2 & 0.69 & $\begin{array}{l}\text { Newtonian } \\
\text { Fluid }\end{array}$ \\
\hline 12 & 1,000 & Polymer 3 & 10,000 & 0.85 & 0.353 & 0.496 & 1 & 0.97 & 0.677 & 0.074 & 2 & 0.91 & $\begin{array}{c}\text { Newtonian } \\
\text { Fluid }\end{array}$ \\
\hline 13 & 10,000 & Polymer 3 & 2,000 & 0.69 & 0.832 & 0.020 & 1 & 0.67 & 0.901 & 0.013 & 2 & 0.68 & $\begin{array}{c}\text { Newtonian } \\
\text { Fluid }\end{array}$ \\
\hline 14 & 10,000 & Polymer 3 & 10,000 & 0.69 & 0.832 & 0.020 & 1 & 0.69 & 0.922 & 0.011 & 2 & 0.69 & $\begin{array}{l}\text { Newtonian } \\
\text { Fluid }\end{array}$ \\
\hline
\end{tabular}


Table 2. Interfarcial Tedence of Polymer with Crude Oil

\begin{tabular}{|c|c|l|c|l|}
\hline No & Sample & \multicolumn{1}{c|}{ Oil } & IFT (mN/M) & Picture \\
\hline 1 & NaCl $1000 \mathrm{ppm}$ & $\begin{array}{l}\text { Light Oil } \\
\text { Densitas }= \\
0.831 \mathrm{~g} / \mathrm{cc}\end{array}$ & 7.666 & \\
\hline 2 & $\begin{array}{l}\text { NaCl } 1000 \mathrm{ppm} \\
+ \\
\text { Polymer } 10.000 \\
\text { ppm }\end{array}$ & $\begin{array}{l}\text { Light Oil } \\
\text { Densitas }= \\
0.831 \mathrm{~g} / \mathrm{cc}\end{array}$ & 9.141 & \\
\hline
\end{tabular}

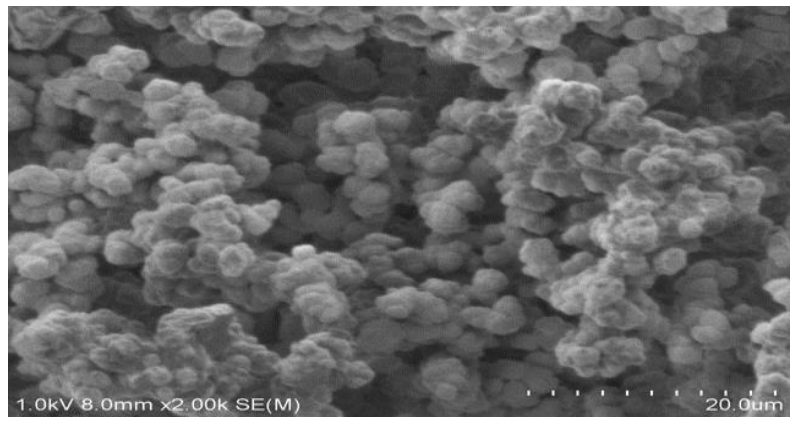

Figure 2 Porosity of Polymer with SEM

\subsection{Create a Discussion}

A Polymer solution is generally classified as a nonNewtonian fluid with brine synthetic solution. The viscosity changes with shear rate and the change is not constant. The following table shows the result of viscosity measured in the EOR laboratory at $50{ }^{\circ} \mathrm{C}$. In total, there are 14 measurement of solutions (standard solution and polymer solutions). There are two standard solution is used; synthetic brine $\mathrm{NaCl} 1,000 \mathrm{ppm}$ and $10,000 \mathrm{ppm}$. For polymer solutions, there are 12 measurements that varied between standard solution and polymer concentration (1,000 ppm and $10,1000 \mathrm{ppm})$ for 3 types of polymer. In general, the polymer viscosities still the same with standard solutions, and in the range of $0.65 \mathrm{cP}-0.69 \mathrm{cP}$. Most of the polymer solutions shows as newtonian fluid and the viscosity is not function of shear rate. There is an anomaly of polymer 3 solution $(10,000 \mathrm{ppm})$ which has been made from $1,000 \mathrm{NaCl}$ standard solution. This measurement shows inconsistency and it can be seen from the value of power law coefficient and constant ( $\mathrm{n}$ and $\mathrm{K}$ parameters), and tends to have higher viscosity than the others polymer solutions. The viscosity of this polymer solution shows in the range of $0.85 \mathrm{cP}-0.97 \mathrm{cP}$ while the others are in the range of $0.65 \mathrm{cP}-0.69 \mathrm{cP}$. Table 2 shows the result of interfacial tension measurement for selceted polymer solutions; Polymer 3 10,000 ppm ( $\mathrm{NaCl} 1,000 \mathrm{ppm})$. The measurement use light oil with $0.831 \mathrm{~g} / \mathrm{cc}$ in density. As a standard, a measurement interfacial tension for standard solution $\mathrm{NaCl}$ 1,000 ppm also has been performed. Based on the result, there is no significant difference between polymer solution and standard solution. The interfacial tension of polymer solution is bit higher than standard solution, which is $9.141 \mathrm{mN} / \mathrm{m}$ and $7.666 \mathrm{mN} / \mathrm{m}$ respectively. The SEM results show that polumer with the higher ratio of porogen has a good porosity

\section{CONCLUSION}

Based on this research was done, it can be concluded that the optimum composition variation for monomer and croslinker is obtained at a variation of 80:20 percent. The 3 rd polymer provides a fairly good interaction with crude oil and The interaction between polymer and crude oil is still unstable due to its porogen nature which is not yet effective. The viscosity and interfacial measurement has been performed in the standard solution and varied polymer concentrations. In general, the polymer viscosities still the same with standard solutions, and in the range of $0.65 \mathrm{cP}-0.69 \mathrm{cP}$. There is an anomaly of polymer 3 solution $(10,000 \mathrm{ppm})$ which has been made from $1,000 \mathrm{NaCl}$ standard solution. The viscosity of this polymer solution shows in the range of $0.85 \mathrm{cP}-0.97 \mathrm{cP}$. There is no significant difference between polymer solution and standard solution. The interfacial tension of polymer solution is bit higher than standard solution, which is $9.141 \mathrm{mN} / \mathrm{m}$ and $7.666 \mathrm{mN} / \mathrm{m}$ respectively and good porosity polymer was developed for EOR study.

\section{ACKNOWLEDGMENTS}

The authors would like to thank the PEM Akamigas for the sponsor. This work was financially supported by the unit UPPM of PEM Akamigas. And The author is deeply indebted to the many co-workers whose names appear in the references.

\section{REFERENCES}

[1] Wanfen. P, Chao. S, Bing. W, Yang. Y and Yibo. L., "Journal of Industrial and Engineering Chemistry", pp 1-11, 2018.

[2] Dimitrios. G. H, Nils. H. G and Arne. S., "Chemical Engineering Science” no. 187 pp. 302-317, 2018.

[3] Xiaoliang. Z, Zhenhua. R and Xinwei. L., "Journal of Natural Gas Science and Engineering” no. 29, pp 275-283, 2016 